\title{
The Hidden Curriculum Undone: Teaching Institutional Knowledge to Transnational Families
}

\author{
Hadyn B. Call ${ }^{1}$ and J. Spencer Clark², Ph.D. \\ ${ }^{1}$ School of Teacher Education and Leadership, Utah State University, Logan, UT, United States \\ ${ }^{2}$ Department of Curriculum and Instruction, Kansas State University, Manhattan, KS, United States \\ Email: hadyncall@aggiemail.usu.edu
}

\begin{abstract}
This article analyzes one aspect of the hidden curriculum perpetuated throughout public education-transnational families lacking institutional knowledge. This is an effort to combat unwanted ignorance by both the dominant culture and those who are attempting to assimilate. It is an effort to prevent injustices that are currently being addressed after the fact rather than as a preventative measure. In essence, we seek to provide a concrete solution to the hidden curriculum of institutional knowledge by proposing that it becomes a part of the community curriculum - a term we are introducing as a way to make explicit the overlooked, and the underutilized normative cultural knowledge. This article also discusses possible directions for future research and how scholars can make the hidden curriculum known by making it explicit in the community curriculum.
\end{abstract}

Keywords: Hidden curriculum, institutional knowledge, transnational, achievement gap, segregated classrooms.

\section{$1 \quad$ Introduction}

Human beings are mobile creatures and have been on the move since time immemorial. Non-sedentary indigenous peoples worldwide traveled, camped, and sustained themselves by following animal herds and gathering nuts, roots, and berries as the seasons permitted. They had no borders.

With developments in technologies our hunter-gatherer ancestors became more sedentary. Farming and irrigation revolutionized the world and made it possible to stay in one place for long periods of time. However, various changes, perhaps from drought, deforestation, over farming, or the invasion of enemy peoples, forced people to move.

Today people find themselves in a very different environment, yet have similar challenges when it comes to moving around the globe. Violence, genocide, hunger, economic turmoil, and better opportunities are a few examples of why people move from one place to another, often crossing borders that have been put in place by nation-states worldwide. While these borders have their purposes, they often divide people not only physically, but culturally as well. Such cultural transitions can be and often are, challenging for those who are engaged in the process.

\section{Transnationals}

Those who arrive in the United States each year add to the richness, culture, and diversity of this nation. Unfortunately, negative stereotypes about immigrant families pervade Eurocentric views throughout the United States, views that are accepted and unchallenged (Moll, Amanti, Neff, \& Gonzalez, 1992, p. 134). Often, "working-class immigrant students and their families are understood as deficient and in need of being fixed" (Kasun, 2014, p.154). Unfortunately, such views are not an exception among educators, under whose tutelage are millions of students and an immeasurable civic responsibility. Research suggests that these students are anything but deficient (Kasun, 2014). On the contrary, many immigrant students are equipped with knowledge that spans cultural and political borders. These students, and those with whom they live, are transnational. They are border crossers, and "the border in this sense is not just an arbitrary geographical line or fence for keeping people in or out, but it is a bridge for people trying to maintain their ties in two countries and to have the best of both worlds" (Browning-Aiken, 2005, p. 179). 
Transnational families across the United States use their funds of knowledge, "the essential cultural practices and bodies of knowledge and information that households use to survive, to get ahead, or to thrive" (Moll, 1992, p. 21). Simply put, funds of knowledge are the "totality of experiences" (Moll et. al., 1992, p. 132), transnational families use as a mechanism to adapt to a country full of opportunity and misfortune, hope and despair (p. 133). Transnational funds of knowledge, however, are insufficient for K-12 students and their families, particularly when it comes to successfully maneuvering through the public school system. The hidden curriculum with which this article is concerned is the expectation of individuals to know the "system" without being explicitly taught about it. Today's educational system does not teach transnational families how public school works. Transnational families lack institutional knowledge and this, unfortunately, creates a colossal disadvantage.

Transnational families need to acquire institutional knowledge. We believe that we cannot afford to wait for the educational system to change, to catch up with the times, to implement all of the culturally responsive pedagogies advocates' desire (Villegas \& Lucas, 2002). While there are many compelling arguments against an assimilationist mentality (Banks, 1975, p. 171), transnational families would do well to become institutionally savvy. They need to know how the school systems their children attend function. The success of their student in such a system depends on it. By no means is this a call to perpetuate the dominant cultural hegemony, to disregard one's rich culture or funds of knowledge. On the contrary, such background is essential for growth and understanding. Nevertheless, as transnational families join the ranks of Americans, and as they enroll their children into public schools, they must acquire institutional knowledge.

We are advocates for introducing transnational families' institutional knowledge. As mentioned, we do not have time to wait for the educational system to change. We must act now to help transnational students succeed. Success could increase exponentially with such knowledge. The systems in place today, unfortunately, are set up in a backwards manner, and tend to focus on remediation rather than prevention. One of the best examples of this backwardness is through the poetic words of Joseph Malins (1936) in his poem called "The Fence or the Ambulance:"

'Twas a dangerous cliff, as they freely confessed,

Though to walk near its crest was so pleasant;

But over its terrible edge there had slipped

A duke, and full many a peasant. So the people said something would have to be done,

But their projects did not at all tally; Some said, "Put a fence around the edge of the cliff,"

Some, "An ambulance down in the valley."

But the cry for the ambulance carried the day, For it spread through the neighboring city;

A fence may be useful or not, it is true, But each heart became brimful of pity

For those who slipped over that dangerous cliff;

And the dwellers in highway and alley

Gave pounds or gave pence, not to put up a fence,

But an ambulance down in the valley.

"For the cliff is all right, if you're careful," they said,

"And, if folks even slip and are dropping,

It isn't the slipping that hurts them so much,

As the shock down below when they're stopping."

So day after day, as these mishaps occurred,

Quick forth would these rescuers sally

To pick up the victims who fell off the cliff,

With their ambulance down in the valley.

Then an old sage remarked: "It's a marvel to me That people give far more attention

To repairing the results than to stopping the cause, When they'd much better aim at prevention.

Let us stop at its source all this mischief," cried he, "Come, neighbors and friends let us rally; 
If the cliff we will fence we might almost dispense

With the ambulance down in the valley."

"Oh, he's a fanatic," the others rejoined,

"Dispense with the ambulance? Never!

He'd dispense with all charities, too, if he could;

No! No! We'll support them forever.

Aren't we picking up folks just as fast as they fall?

And shall this man dictate to us? Shall he?

Why should people of sense stop to put up a fence,

While the ambulance works in the valley?"

But a sensible few, who are practical too,

Will not bear with such nonsense much longer;

They believe that prevention is better than cure,

And their party will soon be the stronger.

Encourage them then, with your purse, voice, and pen,

And while other philanthropists dally,

They will scorn all pretense and put up a stout fence

On the cliff that hangs over the valley.

Better guide well the young than reclaim them when old,

For the voice of true wisdom is calling,

"To rescue the fallen is good, but 'tis best

To prevent other people from falling."

Better close up the source of temptation and crime

Than to deliver from dungeon or galley;

Better put a strong fence round the top of the cliff

Than an ambulance down in the valley.

Today's transnational students are being picked up in educational ambulances and rushed to educational hospitals in an attempt to do surgery on educational failures. Why are we not stopping the calamities before they fall off the cliff? By teaching our transnational families institutional knowledge, by teaching them how the system works in the schools, we can prevent educational accidents well before they happen. We can ensure their success now, rather than remediate their failures in the future.

\section{The Hidden Curriculum}

Educational scholars undoubtedly agree that a hidden curriculum exists in the educational system in the United States of America. Such scholars, however, differ in their views on such a curriculum and how to define its meaning. It is important to view these differences, and then to define the term in a manner conducive to this article. Kentli (2009) provides a comprehensive table reproduced and adapted below as Table 1: Definitions of Hidden Curriculum (pp. 84-86) that defines hidden curriculum in multifarious ways.

Table 1. Definitions of hidden curriculum

\begin{tabular}{l|l|l}
\hline Author & Book/Article & Definition \\
\hline $\begin{array}{l}\text { Emile } \\
\begin{array}{l}\text { Durkheim } \\
(1961)\end{array}\end{array}$ & Moral education & $\begin{array}{l}\text { Durkheim observed that more is taught and learned in schools than } \\
\text { specified in the established curriculum of textbooks and teacher } \\
\text { manuals. Even though it is not directly mentioned as 'hidden } \\
\text { curriculum,' this refers to hidden curriculum. }\end{array}$ \\
\hline
\end{tabular}




\begin{tabular}{|c|c|c|}
\hline $\begin{array}{l}\text { Philip } \\
\text { Jackson } \\
\text { (1968) }\end{array}$ & Life in classrooms & $\begin{array}{l}\text { Learning to wait quietly, exercising restraint, trying, completing } \\
\text { work, keeping busy, cooperating, showing allegiance to both } \\
\text { teachers and peers, being neat and punctual, and conducting } \\
\text { oneself courteously. }\end{array}$ \\
\hline $\begin{array}{l}\text { Robert } \\
\text { Dreeben } \\
(1967)\end{array}$ & $\begin{array}{l}\text { What is learned in } \\
\text { classroom? }\end{array}$ & $\begin{array}{l}\text { The hidden curriculum makes the pupils to form transient social } \\
\text { relationships, submerge much of their personal identity, and accept } \\
\text { the legitimacy of categorical treatment. }\end{array}$ \\
\hline $\begin{array}{l}\text { Elizabeth } \\
\text { Vallance } \\
(1973)\end{array}$ & $\begin{array}{l}\text { Hiding the hidden } \\
\text { curriculum: An } \\
\text { interpretation of the } \\
\text { language of justification in } \\
\text { nineteenth-century } \\
\text { educational reform }\end{array}$ & $\begin{array}{l}\text { The "unstudied curriculum," the "covert" or "latent" curriculum, } \\
\text { the "non-academic outcomes of schooling," the "by-products of } \\
\text { schooling," the "residue of schooling," or simply "what schooling } \\
\text { does to people." }\end{array}$ \\
\hline $\begin{array}{l}\text { Samuel } \\
\text { Bowles \& } \\
\text { Herbert } \\
\text { Gintis (1976) }\end{array}$ & $\begin{array}{l}\text { Schooling in capitalist } \\
\text { America }\end{array}$ & $\begin{array}{l}\text { Schools are not as an agency of social mobility but as reproducing } \\
\text { the existing class structure, sending a silent, but powerful message } \\
\text { to students with regard to their intellectual ability, personal traits, } \\
\text { and the appropriate occupational choice and this takes place } \\
\text { through the hidden curriculum. }\end{array}$ \\
\hline $\begin{array}{l}\text { Jane Martin } \\
(1976)\end{array}$ & $\begin{array}{l}\text { What should we do with a } \\
\text { hidden curriculum when we } \\
\text { find one? }\end{array}$ & $\begin{array}{l}\text { Hidden curriculum can be found in the social structure of the } \\
\text { classroom, the teacher's exercise authority, the rules governing the } \\
\text { relationship between teacher and student. Standard learning } \\
\text { activities can be found also to be sources, as can the teacher's use } \\
\text { of language, textbooks, tracking systems, and curriculum priorities. }\end{array}$ \\
\hline $\begin{array}{l}\text { Paul Willis } \\
(1977)\end{array}$ & Learning to labour & $\begin{array}{l}\text { The hidden curriculum of the school structure which is most } \\
\text { important in determining the reproduction of class relations in } \\
\text { schools; rather, it is the hidden curriculum of pupil resistances } \\
\text { (cultural production) that must be understood if the dynamics of } \\
\text { social and cultural reproductionism is to be explained. }\end{array}$ \\
\hline $\begin{array}{l}\text { Jean Anyon } \\
(1980)\end{array}$ & $\begin{array}{l}\text { Social class and the hidden } \\
\text { curriculum of work }\end{array}$ & $\begin{array}{l}\text { The hidden curriculum of schoolwork is tacit preparation for } \\
\text { relating to the process of production in a particular way. Differing } \\
\text { curricular, pedagogical, and pupil evaluation practices emphasize } \\
\text { different cognitive and behavioral skills in each social setting and } \\
\text { thus contribute to the development in the children of certain } \\
\text { potential relationships to physical and symbolic capital, to } \\
\text { authority, and to the process of work. }\end{array}$ \\
\hline $\begin{array}{l}\text { Michael } \\
\text { Apple (1982) }\end{array}$ & Education and power & $\begin{array}{l}\text { He emphasized that hidden curriculum involves various interests, } \\
\text { cultural forms, struggles, agreements, and compromises. }\end{array}$ \\
\hline $\begin{array}{l}\text { Henry Giroux } \\
(1983)\end{array}$ & $\begin{array}{l}\text { Theories of reproduction and } \\
\text { resistance in the new } \\
\text { sociology of education: A } \\
\text { critical analysis }\end{array}$ & $\begin{array}{l}\text { He defines hidden curriculum as those unstated norms, values, and } \\
\text { beliefs embedded in and transmitted to students through the } \\
\text { underlying rules that structure the routines and social relationships } \\
\text { in school and classroom. }\end{array}$ \\
\hline
\end{tabular}

The ten preceding definitions of the hidden curriculum serve as a representation of the many interpretations held by scholars. However, I find it necessary to expound on my interpretation of its meaning and offer solutions.

The hidden curriculum encompasses all implicit information dealing with education because "it posits a network of assumptions that ... establishes the boundaries of legitimacy" (Apple, 2004, p. 81). It is an expectation held by educational institutions, their staff, and the dominant culture that all stakeholders, regardless of the social, cultural, political, religious, linguistic, or national origins, comprehend the tacit information. Furthermore, "most of the learning rules or guidelines that form part of the hidden curriculum reflect white dominant culture values, practices, and worldviews" (Rahman, 2013, p. 660). In short, the hidden curriculum is the institutional knowledge that stakeholders must have in order to succeed in the educational system. It is the "informal or implicit curriculum" (Vang, 2006, p. 20), the "curriculum outside the official curriculum" (Sari \& Doganay, 2009, p. 926). Since transnational families 
come from outside the border, it is probable that they lack institutional knowledge and therefore lack the tools, information, and knowledge necessary for the success of their children as students in U.S. schools.

Transnational students find themselves in a situation similar to their parents, but because they are the ones immersed in the educational system, it is their academic outcomes that are being influenced, most of the time, negatively (Raham, 2013, p. 670). Interestingly, in the U.S. students are "taught about many cultures, but they are not taught about the English-speaking culture," yet, "they are expected to conform to a culture and a language from which they are kept isolated" (Vang, 2006, p. 24). Such isolation creates the need to remediate, or as the poem demonstrated, to provide ambulances at the bottom of the cliff. It is time to build a protective fence at the top of the cliff so that no one falls in the first place. It is time to include them in all aspects of the curriculum - implicit or explicit.

\section{The Achievement Gap}

One of the most common issues discussed in today's educational system in the United States is the achievement gap (Ladson-Billings, 2006, p. 3). The achievement gap typically "refers to the disparities in standardized test scores between Black and White, Latina/o and White, and recent immigrant and White students," (Ladson-Billings, 2006, p. 3). Recent immigrant children are transnational students and are among those who are considered "behind." Researchers have also concluded that race/ethnicity, socioeconomic status, poverty, low parental education levels, and low parental involvement are all associated with low academic achievement (Lee \& Bowen, 2006, pp. 193-194). Many of these factors are influenced by transnationals' social and cultural capital.

Social capital has been described as, "the obligations and expectations of reciprocity in social relationships, norms and social control, and information channels" as well as "a means to an end, for example, a means by which parents can promote their children's school achievement and educational attainment" (Lee \& Bowen, 2006, p. 196). There are many factors that influence a person's social capital, and those that suffer the inequalities of that realm can cross racial and ethnic lines, as factors such as poverty do not discriminate. Nevertheless, transnational families are likely to be among those that suffer from the inequalities of social capital. For example, "one source of inequality in access to relationships and resources ... is the fit between an individual's culture and the culture of the larger society or the institutions in that society" (Lee \& Bowen, 2006, p. 197). One of the major institutions in the United States is our educational system. Ignorance about such an institution greatly limits the chances of success. The same can be said for a person's cultural capital.

Cultural capital applies to the personal dispositions, attitudes, and knowledge gained from experience by parents whose child is a part of the educational system (Apple, 2004, p. 123). It also entails "connections to education-related objects (e.g., books, computers, academic credentials), and connections to education-related institutions (e.g., schools, universities, libraries)" (Lee \& Bowen, 2006, p. 197). Apropos to the saying, "it takes money to make money," Lee and Bowen (2006) acknowledge the value of cultural capital in creating more cultural capital, "the greater an individual's cultural capital, the greater his or her advantage in procuring additional capital that will benefit family members" (p. 197). Not unlike social capital, the knowledge of institutions, particularly the educational system in the United States, factors in the success of individuals, families, and communities. Lee and Bowen (2006) posit, "cultural capital is the advantage gained by middle-class, educated European American parents from knowing, preferring, and experiencing a lifestyle congruent with the culture that is dominant in most American schools" (p. 198). Transnational families who lack institutional knowledge often have lower levels of social and cultural capital (Lee \& Bowen, 2006).

Changes in socioeconomic status and family conditions also contribute to the achievement gap (Lee, 2015, p. 6). Crossing borders, moving from one country to another, changing homes and enrolling in new schools are factors that dramatically change family conditions and are typical of transnational students. Often, such changes affect the socioeconomic status of such families, which widens the achievement gap. While there are programs in place in our educational system to help such students (i.e. ESL endorsement programs for educators), they are struggling, sluggish, and see insignificant gains (Tellez \& Waxman, 2006). Such programs would benefit greatly if transnational families were first taught the 
community curriculum, or institutional knowledge, which is necessary to be successful in the U.S. school system.

\section{$5 \quad$ Segregated Classrooms}

While the achievement gap does refer to disparities between marginalized students and White students on end of level examinations and standardized tests, "it also exists when we compare dropout rates and relative numbers of students who take advanced placement examinations; enroll in honors, advanced placement, and 'gifted' classes; and are admitted to colleges and graduate and professional programs" (Ladson-Billings, 2006, p. 4). In short, the achievement gap contributes to today's segregated classrooms.

Historically, segregated classrooms in various parts of the United States were openly accepted by the dominant White culture in an effort to keep Black students from attending White schools. Segregation was based on deep-rooted misunderstandings, ignorance, prejudice, and racism. Though the practice was abhorrent, it was at least transparent and undeniable. Its opponents and proponents did not deny its existence. Segregated classrooms today are not black and white, neither literally nor figuratively. The challenge of combatting segregation that exists today is complex, and proponents can more easily deny its existence.

Transnational students unfortunately are part of those who find themselves segregated in various classrooms in schools across the nation. While such segregation can take place because of ignorance, prejudice, and racism, another major reason for such segregation is caused by the lack of institutional knowledge, particularly among transnational families, but also among marginalized populations.

The U.S. Department of Education has gathered data that, when analyzed and interpreted, shows how today's segregated classrooms contribute to the achievement gap. Figure 1 below demonstrates the disparity between White students and Black students overall enrollment with enrollment in upper level math among $8^{\text {th }}$ grade students in a New Jersey school district.

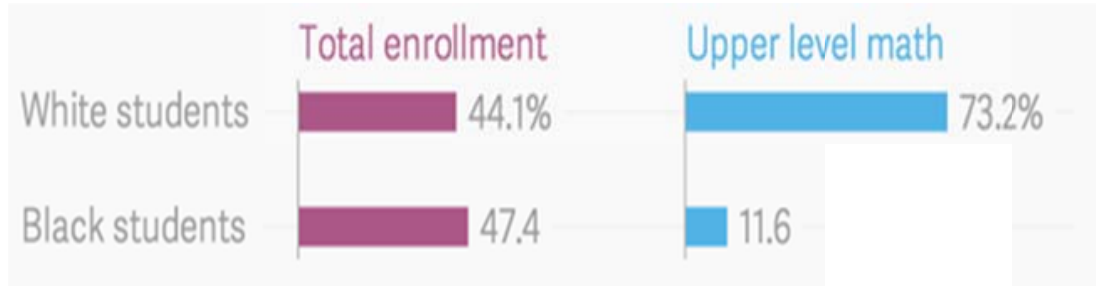

Figure 1. Racial distribution in a New Jersey School District's $8^{\text {th }}$ Grade (U.S. Department of Education as cited in Kohli, 2014)

Although Black students have 3.3\% more students enrolled, Black students have $61.6 \%$ less students enrolled in upper level math than their White counterparts. Figure 2 below demonstrates a similar issue faced by Black high school students from New Jersey in regards to advanced placement courses taken for college credit. Black student enrollment is $13.1 \%$ higher than White student enrollment, however, $51.1 \%$ less Black students are enrolled in advanced placement courses than White students from the same high school.

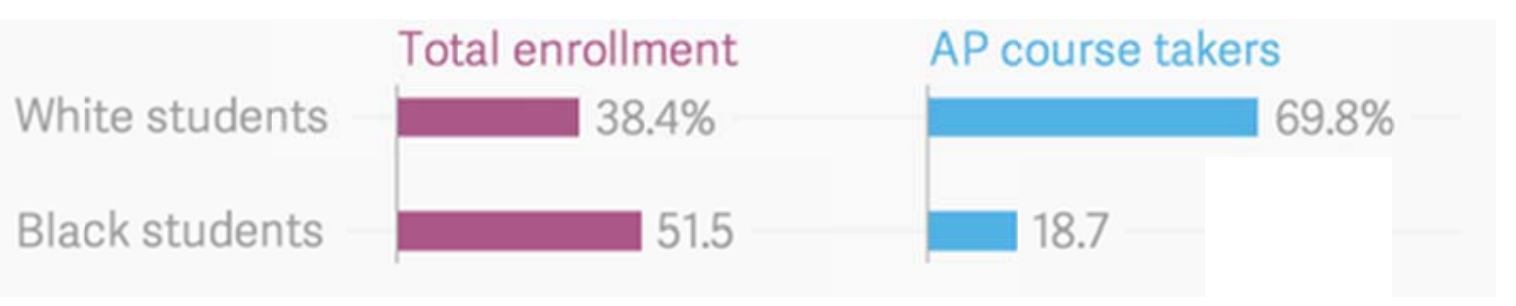

Figure 2. Racial distributions in AP Courses at a high school in New Jersey (U.S. Department of Education as cited in Kohli, 2014) 
A school district in California faces similar disparities. While boasting a very diverse student population, its classrooms are also segregated, and the achievement gap is apparent. Latina and Latino students are the largest group and make up $25 \%$ of the district's population. White students follow closely behind at $24 \%$. Asian student enrollment is $21 \%$ while Black students fall into the teens at $16 \%$. All other groups combined total 13\%. Although White students are the second in enrollment, they are the first among those in gifted and talented education, and the second, only by $1 \%$, among those enrolled in advanced placement courses. Latina and Latino students, who are the highest in enrolled students, fall into the third place with gifted and talented education enrollment, $28 \%$ lower than White students. Latina and Latino students also fall into the third place with advanced placement courses and are $12 \%$ below their White counterparts.

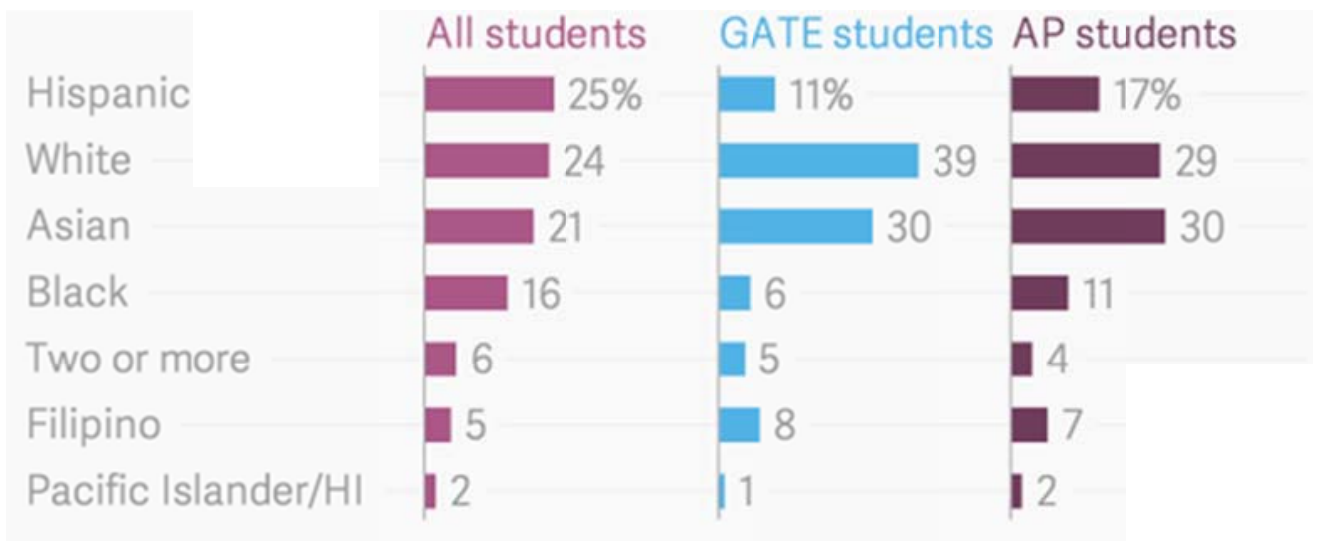

Figure 3. Classroom inequality in a California school district from 2010-2011 (U.S. Department of Education as cited in Kohli, 2014)

Although all educational issues faced in the United States are influenced by a culmination of complex factors, the lack of institutional knowledge plays a major role in the disparities marginalized students face with the achievement gap and segregated classrooms. By teaching institutional knowledge, particularly among transnational families, we can help reduce the achievement gap. Students and families in our educational systems must know how such systems function in order for them to experience success. We must teach our transnational students and their families the community curriculum by uncovering what has been hidden far too long.

\section{Institutional Knowledge}

The concept of institutional knowledge crosses disciplinary boundaries and is applicable to many fields. Institutional knowledge is knowledge about the functions and history of a company or an organization, for example, in the business world, or in a university. Institutional knowledge is also seen as a way to ensure continuity (Pena, 2013). In the field of education, institutional knowledge encompasses the community curriculum, which is the implicit, the overlooked, and the underappreciated normative cultural knowledge that a community has about its educational system.

The following ideas of what transnational families need to know and should be taught are by no means exhaustive. Each district and school should add or adapt according to the needs of their community to fit the community curriculum and the school culture. These solutions serve only as a starting point to what can be taught to transmational families or others wholly ignorant of the system in which their children are supposed to be learning. It is also a starting point for further research, theory development, and empirical studies that can support and further this article's premise. The hope is that we prevent students from needing an "ambulance" by preventing them from "falling off the cliff" initially.

Parental Support. One of the most powerful tools an educational system can have are the parents of the community that send their children to school each day. Parental and community support are paramount to the success of a school. Parents who are involved in their child's education are more likely 
to understand the system in which they are a part. As Lee and Bowen (2006) note, "increasing parent involvement has been identified as a possible strategy for reducing the achievement gap" (p. 194).

Importance of grades. Transnational families have likely experienced some type of educational process outside the bounds of the United States. In the U.S. educational system, teachers provide grades students earn after each term in the school year. While grades are not an "end all" assessment of their student's education, grades are important. The better the grades a student earns the more opportunities they have for future success. One obvious example is the ability to acquire a college or university scholarship. Transnational families should be taught the importance of the grading system, and the implications of grades for their future opportunities.

Reading a report card. Term grades are usually provided on a report card. While report cards from schools and districts differ nationwide, the fundamentals are very similar. In most schools, there is a system of grading that starts with an A, which equals a 4.0 and ends with an $\mathrm{F}$, which equals a 0.0 . Grades in between include $\mathrm{A}-, \mathrm{B}+, \mathrm{B}, \mathrm{B}-, \mathrm{C}+, \mathrm{C}, \mathrm{C}-, \mathrm{D}+, \mathrm{D}$, and $\mathrm{D}-$. These grades are one measurement of academic success that transnational families should understand.

Report cards report more than academics. Many also report a citizenship (a.k.a. behavior) grade. Children's learning is often influenced by their own attitudes and willingness to learn and participate in the academic process. Expectations are in place to ensure a safe learning environment where all kids can feel safe and therefore learn. No system is perfect, however, this is how most schools function. Transnational families would do well to understand this. One example of grading citizenship starts with an $\mathrm{H}$, for Honors, followed by a G, for Good, an S, for Satisfactory, an N, for Needs Improvement, and finally a U, for Unsatisfactory. Striving for satisfactory or honors citizenship grades is a noble task that all students should undertake.

Remediation and making up F's and U's. With the knowledge that good grades are important comes the realization that grades also come with earned credit-credit that allows for eventual graduation. When a student earns an $\mathrm{F}$ in academics and a $\mathrm{U}$ in citizenship they are recommended for remediation so that a student can eventually graduate (assuming the poor grades were earned in the ninth, tenth, eleventh, or twelfth grade). This demonstrates to the student that such remediation is important. Transnational families who lack institutional knowledge may overlook such opportunities at the expense of their children, graduation, and future success.

Graduation requirements and credits. As previously mentioned, passing grades provide credits that lead to graduation. Transnational families are not the only people who might not completely understand graduation requirements and the credit system that it entails. Parents and students who understand what electives, core courses, semester classes versus year classes, etc. are more likely to see that their student is on the right track toward graduation. School guidance counselors are helpful in such matters; however, the responsibility ultimately resides with the student and their guardians.

Among core classes and electives are choices - choices that affect students and their educational outcomes. Many transnational families are unaware of the differences between regular general education courses and advanced placement (AP) classes, concurrent enrollment (CE), and honors. Lacking such knowledge only perpetuates the modern day segregated classrooms where White students greatly outnumber marginalized student numbers enrolled in AP, CE, and honors. Whether transnational students enroll in AP, CE, or honors is one thing, but to be aware of the choices and options they have is another. Schools have a great responsibility to provide this information to all of their students and their families. Agency is a form of empowerment. Transnational families must be empowered.

Behavioral expectations. Citizenship grades are only a part of behavioral expectations that school systems have nationwide. Inside and outside the halls of educational institutions are behavioral expectations that affect individual success. Learning the social norms and values, while not having to necessarily subscribe to all of them, is surely a benefit and an essential part of becoming part of a larger community. As mentioned, "People in the U.S. are taught about many cultures, but they are not taught about the English-speaking culture," yet, "They are expected to conform to a culture and a language from which they are kept isolated" (Vang, 2006, p. 24). Transnational students should be taught about the culture in which they live. They should also be taught that their own culture adds to the richness of the new one of which they are now a part. By no means should one abandon all thoughts, values and beliefs that were held previously. Learning to shake a person's hand or how to dress for an interview can be very beneficial. Knowing when it is appropriate to talk about certain topics, how to respect others, and appropriate use of language is essential for being successful in any culture. 
Rewards and Consequences. Educational institutions provide students with rewards and consequences for certain behaviors, choices, and actions. Parents of all students must become familiar with the consequences of both positive and negative student performance or lack thereof. Transnational students and parents may need explicit instruction on a school's policies and procedures. Certain questions should be addressed: What does it mean to be on the honor roll? What behaviors merit suspension or even expulsion? What is suspension and expulsion? What is the difference between a U from class and an administrative U? Why was my student invited to a student of the month breakfast? Why is my student required to attend an after school homework club? Such questions only touch the surface on the rewards and consequences that are typically understood by the community at large, but not by those new to the system, such as transnational families.

Getting help. Many schools have set in place a plan to help struggling students. Parents who are ignorant of such programs are doing their students a great disservice, however, how would they know of such programs without being informed of their existence? Districts and schools should make available, information that explicitly teaches parents how their student can get the help they need to succeed. That information needs to be accessible to all. Often times the community at large may take for granted the fact that they know about the school website, how to peruse its information, and how to find what they are looking for. Transnational parents and students may be less familiar not only with the technology being used, but how to access it. This should be taught to them.

Making your voice heard. Many transnational families deal with language, cultural, and social barriers due to differing experiences and funds of knowledge. According to Vang (2006), "Parents do not know how to advocate for equity of education for their children even as those students are drowning in school" and "many bilingual parents fear being misunderstood and therefore do not express their concerns if they have any" (p. 22). Parental fears can and should be combatted through the educational process of acquiring institutional knowledge. Students need an advocate and the number one advocate should be their parents or guardians. Despite the difficulties that differing languages and cultures can entail, opportunities must be provided to allow all voices to be heard, including the voices of transnational parents and students. Their concerns should be addressed, and transnational families must be helped to realize that they are valuable stakeholders in the educational system.

Parent-Teacher conferences. One of the first steps that can be taken to make one's voice heard is through attending parent-teacher conferences. Transnational families must be notified of such opportunities well in advance so that arrangements can be made to attend. It is important to let parents know that supporting their student is a major determiner of student success. Lee and Bowen (2006) believe that parent involvement at schools includes attending parent-teacher conferences (p. 194). If and when possible, schools should make arrangements to have translators present to help where needed.

Volunteering. Parent involvement at schools includes volunteer activities (Lee \& Bowen, 2006, p. 194). The more a parent is involved, the more they learn about the educational institution. While it is impossible for all parents to give of their time to help in schools, the opportunities should be presented to all parents, including those that are transnational. It should be made known that language barriers are not a factor in volunteering as opportunities abound.

Homework. A major part of parent involvement includes "help with homework," and just as important, following up with their student by "discussing the child's schoolwork and experiences at school, and structuring home activities" (Lee \& Bowen, 2006, p. 194). Not all parents understand the concept of homework, how it affects grades, performance, or learning, and how they can help their students in completing it. Just because a parent cannot understand an academic concept does not mean they cannot help their child with homework. It starts by simply setting aside time for their student to work. Next, parents must ensure that the environment is conducive to completing the homework that was assigned. Finally, parents can be a major help by following through with their students by helping them stay accountable to the task at hand. Because homework might be a new concept to parents of transnational students, it should be taught explicitly to them.

Financial resources. Life's financial obligations can be daunting for anyone and educational institutions can add to the stress and burden that money, or the lack thereof, can cause. Transnational parents need to be instructed on the financial resources that schools have made available for struggling families. Perhaps many transnationals do not need assistance, however, there may also be those that do need help and lack the knowledge to get it. Free and reduced lunch, fee waivers, and access to the Internet and computers are typical ways in which schools provide help to those in the community that 
need it. If parents are not aware of such opportunities, then how are they expected to take advantage of them?

Contacting the school. One of the most important aspects of education is communication. In today's complex world there are many ways to communicate and educational institutions have adopted several. Emailing teachers and administrators, calling the school, and appearing in person are all typical ways that schools, students, parents, and the community communicate. While such forms of communication seem to be common sense to the community at large, families from differing cultures might not understand and could use help in doing so. Beyond these seemingly simple forms of communication are other modes possibly more difficult for new community members to understand. For example, when a student is absent, many schools have an automated system that calls parents in an effort to inform them of the absence. Other systems are in place to inform parents of school cancelations due to inclement weather or a school emergency. These forms of communication need to be made known to all stakeholders.

Hierarchy of the school system. Institutions have a chain of command. School systems are no exception. Transnational families should receive instruction on the educational systems chain of command. There is, for example, the U.S. Department of Education that oversees the public school system on a national level. State governments oversee the educational needs of their state and typically have a state office of education. They are the connection to the federal government, which often provides funding for different educational programs statewide. Most states are broken into regions called districts where a superintendent and school board oversee educational specialists, administrators, educators, and many other positions that are needed to successfully run and maintain the schools in their boundary. Knowing the hierarchy of the educational system is part of the institutional knowledge or community curriculum that aids in the success of students.

ESL programs and language assistance. Despite some of the issues ESL programs have (Tellez \& Waxman, 2006), they are in an effort to help English Language Learners (ELLs) adjust to the curriculum of the school, the district, and the state. Transnational families should be afforded the opportunity to not only know about the programs offered, but how they are designed to help their student. They should also know that these programs are federally mandated, as decided by the Supreme Court case Lau v. Nichols (1974), which charged the San Francisco school system, "to provide English language instruction to approximately 1,800 Chinese ancestry who do not speak English, or to provide them with other adequate instructional procedures ..." (Office for Civil Rights, 2015). The Supreme Court has also protected the children of immigrant parents through legislation via Plyler v. Doe (1982), where "the U.S. Supreme Court held that states may not deny access to public education to any child residing in the state whether present in the U.S. legally or otherwise" (Center for Education and Employment Law, 2014, p. 20).

Extracurricular activities. The significance of extracurricular activities goes well beyond the social benefits a student may experience or the fun that accompanies many of these after school events. Transnational families, particularly those who are struggling financially, may look the other way when it comes to their son or daughter participating in what seems to be an expensive sport, club, or dance team. This should not inhibit their children from trying out for certain teams, groups, or programs. Extracurricular activities help develop team building, social skills, and often they promote exercise and healthy living choices. They also enhance a resume or college application. Transnational families who are properly taught this information might be more willing to support their children in such endeavors. Extracurricular activities also become a major force behind the culture of a school. Students who participate are more often viewed as part of that culture.

School Clubs. Some types of extracurricular activities can be student driven, student initiated. Likeminded students and supportive teachers often are the founders of new school clubs. Others join clubs that have a long history of supporters that have enjoyed working with or competing against others. Chess clubs nationwide develop strategies that enhance one's ability to dominate the game. Outdoor clubs promote conservation and getting people outside. Art clubs foster creativity and develop useful skills. Other clubs are service oriented and organize community events and activities. Students, including transnationals, can get involved by starting or joining school clubs. But, in order to get involved, one must know how to do so.

College Application process and timing. Most colleges and universities have hard deadlines for when applications are due. Most deadlines are in November and December, and the applications require 
a fee, high school transcripts, and an ACT/SAT score, among other items. Students must be on track for graduation, and their transcripts must contain the proper amount of credit and prerequisites that the college or university may require. While counselors do provide services that render aid to all students, including transnationals, transnational parents too, have a responsibility to know this information and the educational system would benefit as well by helping them to obtain it.

ACT/SAT. The ACT and SAT are college and university entrance exams required by most accredited institutions. Students interested in attending college have the obligation to take one or both of these exams as a prerequisite for the college application process. Scores on each test are calculated differently, 36 being the perfect ACT score, and 2400 being the perfect SAT score. The higher the score, the more likely a student will be accepted into a college or university. High scores also provide more opportunities for scholarships. Many high schools provide ample opportunity to take these tests, sometimes even covering testing fees for a student's first time taking the exam. However, costs do exist, but students can take both tests multiple times in an effort to improve their scores. It is important for students and parents to understand the implications this test has on their future, as well as the importance of completing these exams prior to application deadlines.

Scholarship opportunities. Scholarship opportunities abound; however, many students and parents are wholly ignorant of this fact. Effective high schools provide parents and students with scholarship information; but, language barriers and cultural misunderstandings can inhibit information from being understood. Explicitly teaching about scholarship opportunities to transnational families can effectively help to overcome these obstacles.

Technical training opportunities. Despite today's emphasis on the importance of a college education, not all students are college bound. Other extremely beneficial opportunities are available for students that are not on the college track. Many high schools provide opportunities for technical training that give hands-on job experiences to students interested in welding, HVAC, auto mechanics, plumbing, and electrical. Students can take classes that will give them the basic work experiences required to obtain a job in the previously mentioned fields. Our society needs welders, mechanics, and electricians, to name but three, and the demand for such jobs increases salaries. Transnational students who are not interested in college can still continue to learn and grow in a way that will help them obtain a noble job that provides living wages.

\section{Conclusions}

Transnational families use their funds of knowledge, or "totality of experiences" (Moll et. al., 1992, p. 132) to adapt to their new situations. With rich backgrounds and cultures, transnationals add to the uniqueness of the United States, a country with opportunities that make it "exceptional."

Transnational students are border crossers and have rich life experiences. Many often struggle in the U.S. educational system because of the hidden curriculum, which is the "informal or implicit curriculum" (Vang, 2006, p. 20), the "curriculum outside the official curriculum (Sari \& Doganay, 2009, p. 926). Institutional knowledge, a part of the hidden curriculum, encompasses the community curriculum, which is the implicit, the overlooked, and the underappreciated normative cultural knowledge that a community has about its educational system.

The lack of institutional knowledge contributes to the achievement gap, one of the most talked about terms in education that "refers to the disparities in standardized test scores between Black and White, Latina/o and White, and recent immigrant and White students," (Ladson-Billings, 2006, p. 3). Another contributor to the achievement gap are today's segregated classrooms. Segregated classrooms are as much a part of contemporary education as in times past, albeit in different ways. Transnational enrollment in upper level, AP, CE, and honors courses lags behind White student enrollment.

Programs have been developed to help transnationals but such programs are insufficient, slow, and ineffective (Tellez \& Waxman, 2006). Teaching transnational families explicit information about the educational system, or in short, undoing the hidden curriculum by teaching institutional knowledge, transnational students will not have to be picked up by the "ambulance" after a painfully hard fall, but rather, will be able to be standing proud and tall at the "fence by the cliff" overlooking the endless possibilities that await them as they reach their potential. 


\section{References}

1. Apple, M. W. (2004). Ideaology and curriculum, 3rd ed. New York, NY: Routledge.

2. Banks, J. A. (1975). The implications of ethnicity for curriculum reform. Educational Leadership, 168-172. Retrieved from http://www.ascd.org/ASCD/pdf/journals/ed_lead/el_197512_banks.pdf.

3. Center for Education and Employment Law. (2014). 2015 Deskbook Encyclopedia of American school law. Malvern, PA: Center for Education and Employment Law.

4. Kasun, G. S. (2014). Hidden knowing of working-class transnational Mexican families in schools: bridge-building, Nepantlera knowers. Ethnography and Education, 9(3).

5. Kasun, G. S. \& Saavedra, C. M. (2014). Cross-cultural considerations in the education of young immigrant learners. J. Keengwe and G. Onchwari (Eds.). Hershey, Pennsylvania: IGI Global, 201-217.

6. Kentli, F. D. (2009). Comparison of hidden curriculum theories. European Journal of Educational Studies, 1(2), 83-88.

7. Kohli, S. (2014). Modern day segregation in public schools. The Atlantic. Retrieved from http://www.theatlantic.com/education/archive/2014/11/modern-day-segregation-in-public-schools/382846/.

8. Ladson-Billings, L. (2006). From the achievement gap to the education debt: Understanding achievement in U.S. schools. Educational Researcher, 35(7), 3-12.

9. Lee, J. (2015). Racial and ethnic achievement gap trends: Reversing the progress toward equity? Educational Researcher, 31(1), 3-12.

10.Lee, J., \& Bowen, N. K. (2006). Parent involvement, cultural capital, and the achievement gap among elementary school children. American Educational Research Journal 43(2), 193-218.

11.Malins, J. (1936). A fence or an ambulance. In H. Felleman (Ed.). The best loved poems of the American people (pp. 273-274). New York, NY: Doubleday \& Company, Inc.

12.Moll, L. C. (1992). Bilingual classroom studies and community analysis: Some recent trends. Educational Researcher, 21(2), 20-24.

13.Moll, L. C., Amanti, C., Neff, D. \& Gonzalez, N. (1992). Funds of knowledge for teaching: Using a qualitative approach to connect homes and classrooms. Theory Into Practice, 31(2), 132-141.

14.Office for Civil Rights. (2015). Developing programs for English Language Learners: Lau v. Nichols. Retrieved from http://www.2.ed.gov/about/offices/list/ocr/ell/lau.html.

15.Pena, A. M. (2013). Capturing institutional knowledge. Inside Higher Ed. Retrieved from https://www.insidehighered.com/advice/2013/11/15/colleges-must-work-retain-and-document-institutionalknowledge-essay.

16.Rahman, K. (2013). Belonging and learning to belong in school: The implications of the hidden curriculum for indigenous students. Studies in the Cultural Politics of Education, 34(5), 660-672.

17.Sari, M., \& Doganay, A. (2009). Hidden curriculum on gaining the value of respect for human dignity: A qualitative study in two elementary schools in Adana. Educational Sciences: Theory \& Practice, 9(2), 925-940.

18.Tellez, K., \& Waxman, H. C. (2006). Preparing quality educators for EL: Overview of the critical issues. In K. Tellez \& H. C. Waxman (Eds.), Preparing quality educators for ELs (pp. 1-22). Mahwah, NJ: Lawrence Erlbaum.

19.Vang, C. T. (2006). Minority parents should know more about school culture and its impact on their children's education. Multicultural Educatio, 14(1), 20-26.

20.Villegas, A. M., \& Lucas, T. (2002). Preparing culturally responsive teachers: Rethinking the curriculum. Journal of Teacher Education, 53(1), 20-32. 